\title{
A MORE ACCURATE MULTIDIMENSIONAL HARDY-HILBERT TYPE INEQUALITY WITH A GENERAL HOMOGENEOUS KERNEL
}

\author{
Bicheng YANG AND QIANG CHEN
}

\begin{abstract}
In this paper, by the use of the weight coefficients, the transfer formula, HermiteHadamard's inequality and the technique of real analysis, a more accurate multidimensional Hardy-Hilbert-type inequality with a general homogeneous kernel and a best possible constant factor is given, which is an extension of some published results. Moreover, the equivalent forms, the operator expressions and some particular examples are considered.
\end{abstract}

Mathematics subject classification (2010): 26D15, 47A05.

Keywords and phrases: Hardy-Hilbert-type inequality, weight coefficient, Hermite-Hadamard's inequality, equivalent form, operator.

\section{REFERENCES}

[1] G. H. Hardy, J. E. Littlewood, G. Pólya, Inequalities, Cambridge University Press, Cambridge, USA, 1934.

[2] D. S. Mitrinović, J. E. PeČARIĆ, A. M. FinK, Inequalities involving functions and their integrals and derivatives, Kluwer Acaremic Publishers, Boston, USA, 1991.

[3] B. YANG, Discrete Hilbert-type inequalities, Bentham Science Publishers Ltd., The United Arab Emirates, 2011.

[4] B. YANG, On a more accurate multidimensional Hilbert-type inequality with parameters, Mathematical Inequalities and Applications, vol. 18, no. 2, pp. 429-441, 2015.

[5] Y. Hong, On Hardy-Hilbert integral inequalities with some parameters, J. Ineq. in Pure \& Applied Math., vol. 6, no. 4, Art. 92, pp. 1-10, 2005.

[6] B. YAng, M. KRniĆ, On the Norm of a Mult-dimensional Hilbert-type Operator, Sarajevo Journal of Mathematics, vol. 7, no. 20, pp. 223-243, 2011.

[7] M. KRnić, J. E. PeČARIĆ, P. VuKović, On some higher-dimensional Hilbert's and Hardy-Hilbert's type integral inequalities with parameters, Math. Inequal. Appl., vol. 11, pp. 701-716, 2008.

[8] M. Krnić, P. Vuković, On a multidimensional version of the Hilbert-type inequality, Analysis Mathematica, vol. 38, pp. 291-303, 2012.

[9] M. TH. Rassias, B. YANG, A multidimensional half-discrete Hilbert-type inequality and the Riemann zeta function, Applied Mathematics and Computation, vol. 225, pp. 263-277, 2013.

[10] B. YANG, A multidimensional discrete Hilbert-type inequality, Int. J. Nonlinear Anal. Appl. vol. 5, no. 1, pp. 80-88, 2014.

[11] M. TH. RASSIAS, B. YANG, On a multidimensional half - discrete Hilbert - type inequality related to the hyperbolic cotangent function, Applied Mathematics and Computation, vol. 242, pp. 800-813, 2014.

[12] M. TH. RASSiAS, B. YANG, On a multidimensional Hilbert-type integral inequality associated to the gamma function, Applied Mathematics and Computation, vol. 249, pp. 408-418, 2014.

[13] Q. Chen, B. YANG, On a more accurate multidimensional Mulholland-type inequality, Journal of Inequalities and Applications 2014, 2014:322.

[14] B. YAnG, Q. CHEn, A multidimensional discrete Hilbert-type inequality, Journal of Mathematical Inequalities, vol. 8, no. 2, pp. 267-277, 2014.

[15] B. YANG, On a more accurate reverse multidimensional half-discrete Hilbert-type inequalities, Mathematical Inequalities and Applications, vol. 18, no. 2, pp. 589-605, 2015. 
[16] T. LiU, B. YANG, L. HE, On a multidimensional Hilbert-type integral inequality with logarithm function. Mathematical Inequalities and Applications, vol. 18, no. 4, pp. 1219-1234, 2015.

[17] Z. HuANG, B. YANG, A multidimensional Hilbert-type integral inequality, Journal of Inequalities and Applications (2015), 2015:151.

[18] Y. SHI, B. YANG, On a multidimensional Hilbert-type inequality with parameters, Journal of Inequalities and Applications (2015), 2015:371.

[19] J. ZHONG, B. YANG, An extension of a multidimensional Hilbert-type inequality, Journal of Inequalities and Applications (2017) 2017:78.

[20] V. Adiyasuren, T. Batbold, M. M. Krnić, On several new Hilbert-type inequalities involving means operators, Acta Math. Sin. Engl. Ser. vol. 29, pp. 1493-1514, 2013.

[21] Y. Hong, On multiple Hardy-Hilbert integral inequalities with some parameters, Journal of Inequalities and Applications, vol. 2006, Article ID 94960, 11 pages.

[22] Q. L. HuAng, On a multiple Hilbert's inequality with parameters, Journal of Inequalities and Applications, vol. 2010, Article ID 309319, 12 pages.

[23] I. Perić, P. Vuković, Multiple Hilbert's type inequalities with a homogeneous kernel, Banach Journal of Mathematical Analysis, vol. 5, no. 2, pp. 33-43, 2011.

[24] B. HE, A multiple Hilbert-type discrete inequality with a new kernel and best possible constant factor, Journal of Mathematical Analysis and Applications, vol. 431, pp. 990-902, 2015.

[25] V. Adiyasuren, T. Batbold, M. Krnić, Multiple Hilbert-type inequalities involving some differential operators, Banach J. Math. Anal., vol. 10, no. 2, pp. 320-337, 2016.

[26] B. YANG, An extension of a Hardy-Hilbert-type inequality, Journal of Guangdong University of Education, vol. 35, no. 3, pp. 1-7, 2015.

[27] Y. SHI, B. YANG, A new Hardy-Hilbert-type inequality with multi-parameters and a best possible constant factor, Journal of Inequalities and Applications (2015), 2015: 380.

[28] Q. HuANG, A new extension of Hardy-Hilbert-type inequality, Journal of Inequalities and Applications (2015), 2015: 397.

[29] A. WANG, Q. HUANG, B. YANG, A strengthened Mulholland-type inequality with parameters, Journal of Inequalities and Applications (2015), 2015: 329.

[30] M. TH. RASSIAS, B. YANG, On a Hardy-Hilbert-type inequality with a general homogeneous kernel, Int. J. Nonlinear Anal. Appl. vol. 7 no. 1, pp. 249-269, 2016.

[31] B. YANG, Q. CHEN, On a more accurate Hardy-Mulholland-type inequality, Journal of Inequalities and Applications (2016), 2016: 82.

[32] I. BRnetić, J. E. PeČARIĆ, Generalization of Hilbert's integral inequality, Mathematical inequalities and applications, vol. 7, no. 2, pp. 199-205, 2004.

[33] M. KRniĆ, J. E. PeČARIĆ, General Hilbert's and Hardy's inequalities, Mathematical inequalities and applications. vol. 8, no. 1, pp. 29-51, 2005.

[34] M. KRnić, M. GAO, J. E. PeČARIĆ et. al., On the best constant in Hilbert's inequality, Mathematical inequalities and applications. vol. 8, no. 2, pp. 317-329, 2005.

[35] Y. Li, J. WANG, B. HE, On further analogs of Hilbert's inequality, Journal of Inequalities and Applications, vol. 2007, Article ID 76329, 6 pages.

[36] E. A. LAITH, On some extensions of Hardy-Hilbert's inequality and applications, Journal of Inequalities and Applications, vol. 2008, Article ID 546828, 14 pages.

[37] R. P. Agarwal, D. O'Regan, S. H. Sa Ker, Some Hardy-type inequalities with weighted functions via Opial type inequalities, Advances in Dynamical Systems and Applications, vol. 10, pp. 1-9, 2015.

[38] J. KuAng, Applied inequalities, Shangdong Science Technic Press, Jinan, China, 2004. 